\title{
The importance of orthodontic treatment for the increase of the radical overlay previsibility: Case report
}

\author{
A importância do tratamento ortodôntico para o aumento da previsibilidade do recobrimento \\ radicular: Relato de caso \\ La importancia del tratamiento ortodóntico para aumentar la previsibilidad de cobertura
} radicular: Reporte de caso

Received: 03/03/2021 | Reviewed: 03/23/2021 | Accept: 05/13/2021 | Published: 06/03/2021

Angélica Kercya Pereira de Mendonça
ORCID: https://orcid.org/0000-0002-9769-9633
Federal University of Rio Grande do Norte, Brazil
E-mail: angelica_kercya@ hotmail.com
Renata Suellen Galvão da Silva Costa
ORCID: https://orcid.org/0000-0001-6759-6652
Federal University of Rio Grande do Norte, Brazil
E-mail: renata_sgalvao@yahoo.com.br
Halissa Simplicio Gomes Pereira
ORCID: https://orcid.org/0000-0001-5398-6318
Federal University of Rio Grande do Norte, Brazil
E-mail: hallissa@ hotmail.com
Ruthineia Diógenes Alves Uchôa Lins
ORCID: https://orcid.org/0000-0002-0047-5976
Federal University of Rio Grande do Norte, Brazil
E-mail: aruthineia@ gmail.com
Ana Rafaela Luz de Aquino Martins
ORCID: https://orcid.org/0000-0001-7188-4964
Federal University of Rio Grande do Norte, Brazil
E-mail: anarafaela.luz@ terra.com.br
Bruno Cesar de Vasconcelos Gurgel
ORCID: https://orcid.org/0000-0001-5971-134X
Federal University of Rio Grande do Norte, Brazil
E-mail: bcgurgel@yahoo.com.br
Euler Maciel Dantas

\begin{abstract}
Introduction: Gingival recession is established through several factors and its treatment can be planned integrating surgical procedures with the aid of orthodontic treatment. Methods: In this context, a 36-year-old woman sought dental treatment to realign the right lower central incisor. A localized gingival recession was verified, being related to poor positioning of the root. The patient had undergone previous orthodontic treatment, as well as periodontal surgical treatment, after which there was no success. Results: After the planning of the case, the dental element was reallocated through orthodontic movement and then the periodontal surgical treatment was performed. With the results obtained, the improvement of gingival recession through orthodontic and periodontal surgical treatment is discussed. Conclusions: This clinical report shows that the gingival graft, performed after tooth movement, can increase the probability of good results in reducing root exposure.
\end{abstract}

Keywords: Orthodontics; Gingival Recession; Periodontics.

\section{Resumo}

Introdução: A recessão gengival é estabelecida por vários fatores e seu tratamento pode ser planejado integrando procedimentos cirúrgicos com o auxílio do tratamento ortodôntico. Métodos: Neste contexto, uma mulher de 36 anos procurou tratamento odontológico para realinhar o incisivo central inferior direito. Verificou-se recessão gengival localizada, relacionada ao mau posicionamento da raiz. A paciente havia sido submetida a tratamento ortodôntico prévio, bem como a tratamento cirúrgico periodontal, sem sucesso. Resultados: Após o planejamento do caso, o elemento dentário foi realocado por meio de movimentação ortodôntica e em seguida foi realizado o tratamento cirúrgico periodontal. Com os resultados obtidos, discute-se a melhora da recessão gengival por meio do tratamento 
ortodôntico e cirúrgico periodontal. Conclusões: Este relato clínico mostra que o enxerto gengival, realizado após a movimentação dentária, pode aumentar a probabilidade de bons resultados na redução da exposição radicular.

Palavras-chave: Ortodontia; Recessão gengival; Periodontia.

\section{Resumen}

Introducción: La recesión gingival se establece por varios factores y su tratamiento puede planificarse integrando procedimientos quirúrgicos con la ayuda del tratamiento de ortodoncia. Métodos: En este contexto, una mujer de 36 años solicitó tratamiento odontológico para realinear el incisivo central inferior derecho. Hubo una recesión gingival localizada, relacionada con el mal posicionamiento de la raíz. La paciente había sido sometida previamente a un tratamiento de ortodoncia, así como a un tratamiento quirúrgico periodontal, sin éxito. Resultados: Luego de planificar el caso, se reubicó el elemento dental mediante movimiento de ortodoncia y luego se realizó tratamiento quirúrgico periodontal. Con los resultados obtenidos, se discute la mejora de la recesión gingival mediante el tratamiento quirúrgico de ortodoncia y periodontal. Conclusiones: Este informe clínico muestra que el injerto gingival, realizado después del movimiento del diente, puede aumentar la probabilidad de obtener buenos resultados en la reducción de la exposición radicular.

Palabras clave: Ortodoncia; Recesión gingival; Periodoncia.

\section{Introduction}

Gingival recession can be attributed to several factors, whose primary causes are the presence of biofilm and trauma of brushing. Defective habits, poor dental positioning and abnormal brake insertion may also contribute to the occurrence of gingival recession if biofilm is present at the site (Machado et al., 2004; Cairo, 2017; Zavanelli et al., 2018). In a fully healthy periodontium, a well-planned orthodontic movement does not produce detrimental effects (Ericsson et al., 1977; Ericsson et al., 1978; Polson et al., 1984).

However, although there is no consensus in the literature, orthodontic movement may facilitate the development of gingival recession, especially in cases where the movement of the dental elements occurs through an excessive force for vestibular or lingual / palatal. Therefore, it occurs the displacement of the dental root out of the proper positioning within the alveolar bone, which can generate regions of bone dehiscence and, potentially, gingival recession (Richman, 2011; Morris et al., 2017; Sharma et al., 2017; Ji et al., 2019).

The orthodontic movement generates areas of pressure and tension in the periodontium, both at the margins and apically, and the osteogenic potential results in bone resorption and apposition (Matsumura et al., 2017). Therefore, this biological process can also result in the correction of periodontal defects. However, it is important to emphasize that in the presence of biofilm, the orthodontic movements of inclination and intrusion within the alveolar bone can lead to the damage of the periodontium (Ericsson et al., 1977).

The repositioning of highly vestibularized roots or periodontally extruded teeth may facilitate the treatment of the recession, preparing the clinical aspect for a later approach through periodontal surgery, which has demonstrated favorable clinical results in the reconstruction of intraosseous defects, with the stability of the treated area and the solutions for the reconstruction of the mucogingival region in areas of gingival recession (Heitz-Mayfield et al., 2002; Esposito et al., 2005).

The authors report that there is a possibility of treating periodontal defects using orthodontic treatment in combination with periodontal treatment in patients with poorly positioned dental elements (Machado et al., 2004; Rotundo et al., 2011). Therefore, the objective of this article is to present a clinical case of a patient who underwent orthodontic treatment for the alignment of a tooth that presented Muller's class III gingival recession and subsequent surgery for root coverage, in addition to discussing the impact of orthodontic treatment in the continuing of the case.

\section{Methodology}

It is a qualitative case report, which consists of a careful and detailed description of the diagnosis and evolution of the disease of a patient, which has peculiar characteristics that make it particular to be analyzed and detailed (Pereira et al., 2018). 
The patient signed a term of commitment to use data and authorization in her medical record, for the use of information in teaching, research and publications.

\section{Case Report}

A 36-year-old woman patient attended the clinic for an evaluation of the right lower central incisor, which had previously been submitted to a free gingival graft and, after a result of the therapy, still presented great radicular exposure (Fig. 1). She had also undergone orthodontic treatment for about a year.

Figure 1. Presence of class III gingival recession (Miller, 1985).

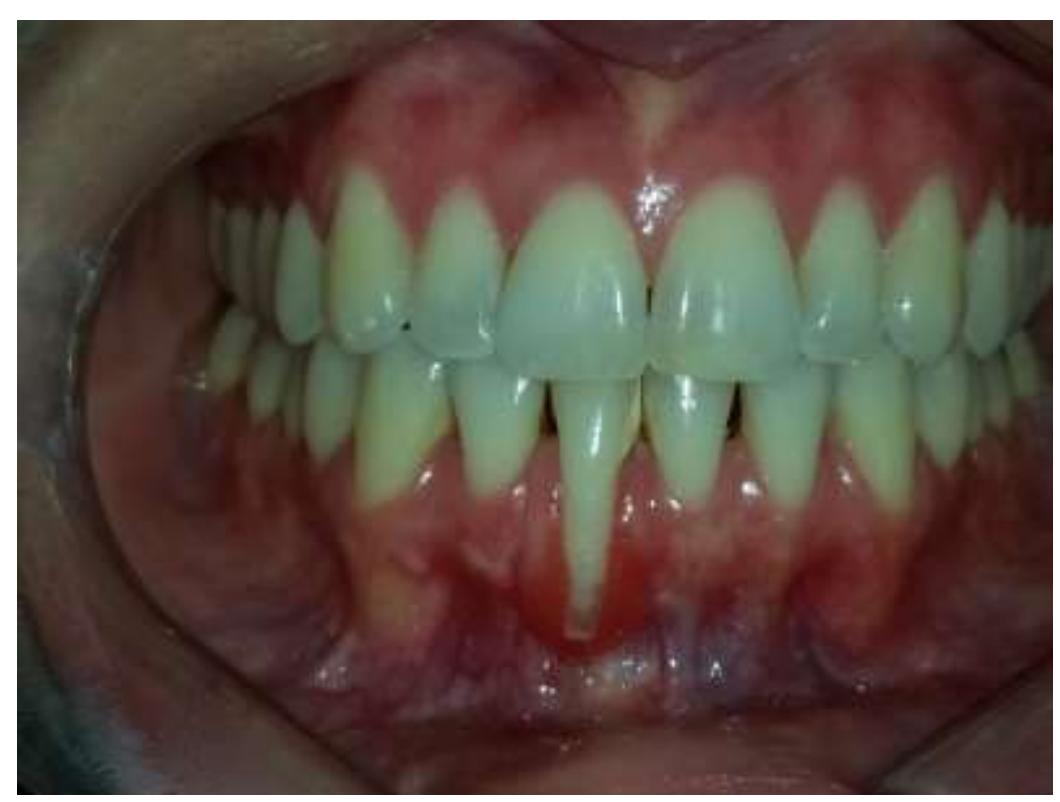

Source: Authors.

At the initial clinical examination, it was observed that the dental element presented with a grinding recess of 8 (eight) mm Class III of Miller, characterized by a recession of the marginal tissue that extends to or beyond the mucogingival junction, where there is loss of the bone or of the soft tissue (Miller, 1985). In addition, the positioning of the dental root is found for the vestibular of the dental arch (Figure 2) and Figure 3 shows the initial radiographic aspect (Figure 3). 
Research, Society and Development, v. 10, n. 6, e36510613526, 2021

(CC BY 4.0) | ISSN 2525-3409 | DOI: http://dx.doi.org/10.33448/rsd-v10i6.13526

Figure 2. Positioning of the dental root for the vestibular of the dental arch.

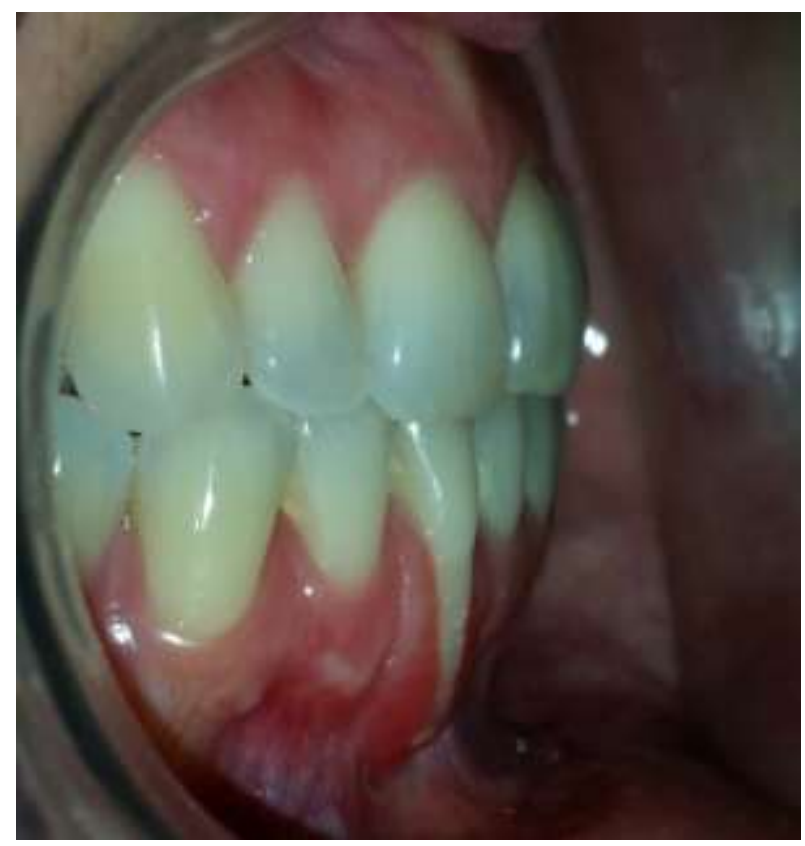

Source: Authors.

The root presented vestibularization in relation to adjacent teeth and root exposure to the apical region (Figure 2). There was absence of inserted gingiva, with consequent accumulation of biofilm and presence of severe gingival inflammation in the site.

Figure 3. Initial radiographic aspect.

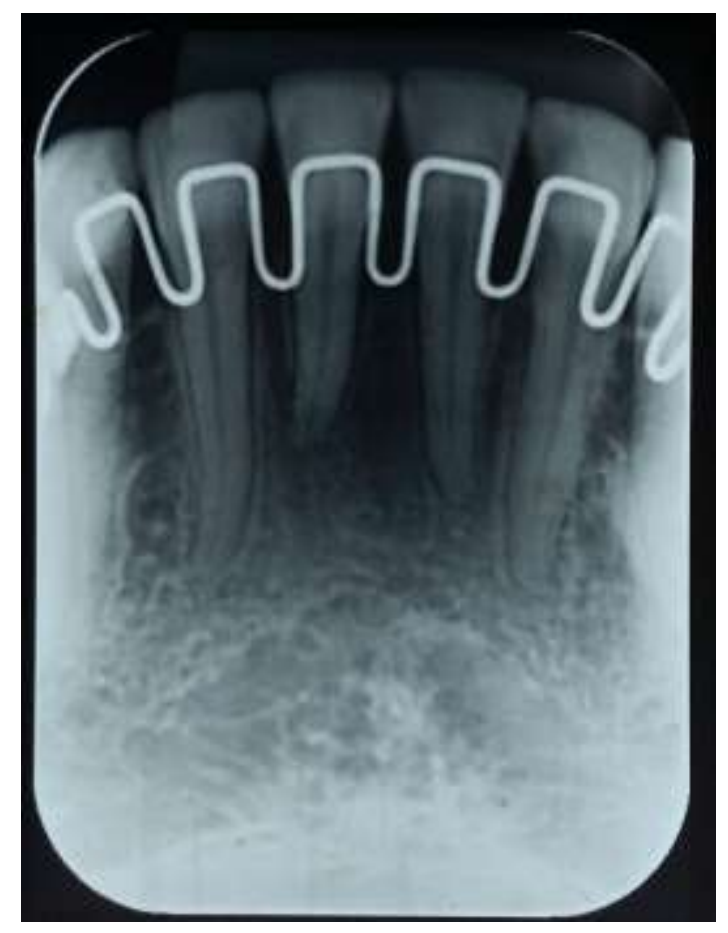

Source: Authors. 
The radiographic examination showed a loss of interproximal bone and a continuity of the hard blade (Fig. 3). Despite the loss of support, there was no dental mobility.

\section{Treatment goals}

Maintenance of the dental element, in order to partially cover the gingival recession.

\section{Treatment alternatives}

To obtain the best possible result, the proposed treatment plan was the most appropriate option for the clinical case in question.

\section{Plan of treatment}

After the determination of the diagnosis, the treatment plan, which included basic periodontal therapy (orientation and motivation of oral hygiene, scaling and corono-radicular straightening), occlusal adjustment in the dental element through selective wear with a diamond tip, was explained, due to the presence of premature contact and occlusal interference, as well as endodontic treatment and orthodontic movement to the lingual direction, aiming to align the dental element with adjacent teeth. At that moment it was discussed about the prognosis of the dental element that would be the attempt of maintenance of the same with possibility of partial covering of the recession.

\section{Results}

\section{Treatment progress}

In the first session, patient's motivation procedures were performed, as well as the demonstration of brushing techniques, including standard brushes, and the use of dental floss. The patient already showed a desire not to lose the tooth, which facilitated the motivation regarding the control of the dental biofilm. Then, scaling and root planning with Mini-five 5-6 curettes (Hu-Friedy) were performed (Figure 4).

After 45 (forty-five) days, a periodontal reassessment was performed. There was improvement in the bleeding rates, biofilm presence, depth of probing and gingival tissue characteristics. The patient was referred for endodontic treatment of the right lower central incisor and, later, for orthodontic movement.

Figure 4. Aspect of the gingival after the basic periodontal therapy and orthodontic treatment for the movement of the element 41.

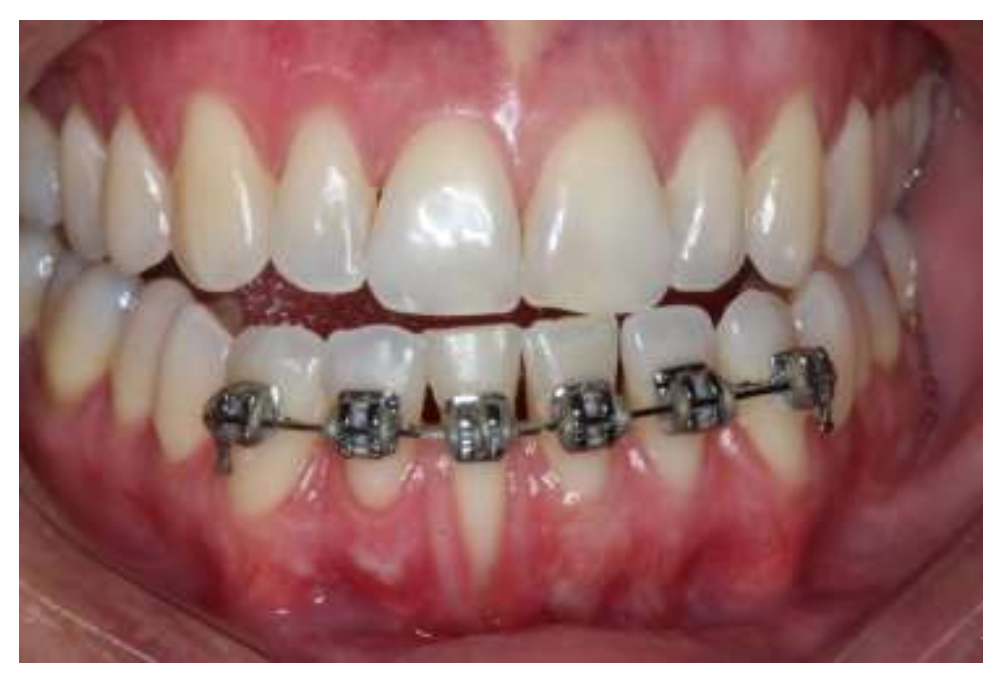

Source: Authors. 
The orthodontic treatment lasted for ten (10) months and a $0.17 \times 0.25$ steel wire was used and the root lingual torque was performed (Figure 4). Figure 5 shows the result of root movement after orthodontic treatment (Figure 5).

Figure 5. Root movement after orthodontic treatment.

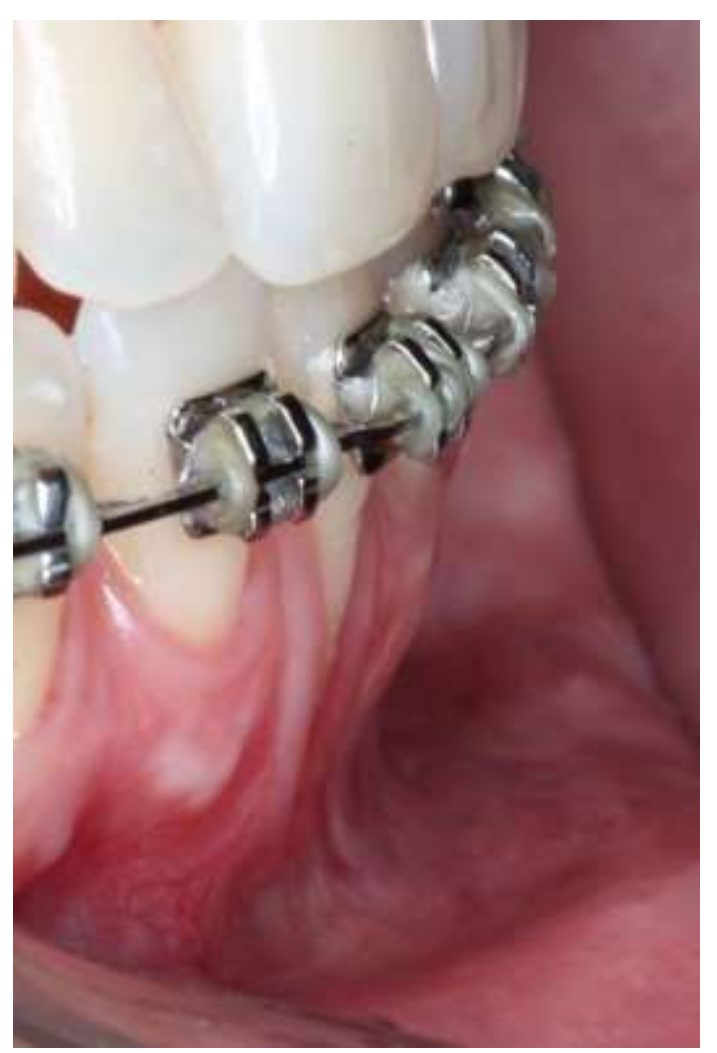

Source: Authors.

After finishing the orthodontic movement, it was verified that the lingualization of the tooth led to a decrease in the width and convexity of the exposed root, which favored a better prognosis of the tooth (Figure 5). After two (2) months, periodontal surgery was performed with the aim of the root canal, but mainly with the aim of changing the periodontal biotype. We chose to perform the subepithelial connective graft technique (Zanicotti et al., 2009) associated with the dual papilla flap technique (Bom et al., 2005) (Figure 6 and Figure 7). 
Figure 6. Graft donor area.

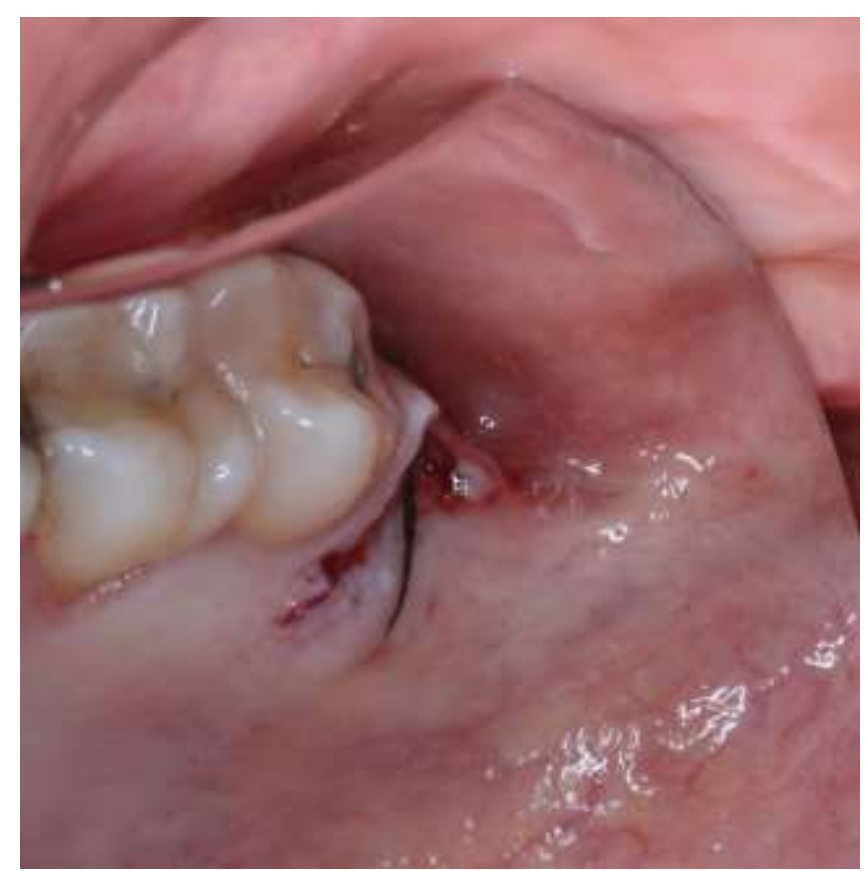

Source: Authors.

The coating technique consisted of a removal of the epithelium from the margins of the gingival recession through the use of a scalpel blade 15c; sulcular incision; a split flap was then made, preserving the margin of the adjacent papillae, providing space for the insertion of the connective tissue graft and the movement of the flap to the graft covering, from the maxillary tuberosity region (Figure 6), and the was root previously exposed.

Figure 7. Final appearance of the graft.

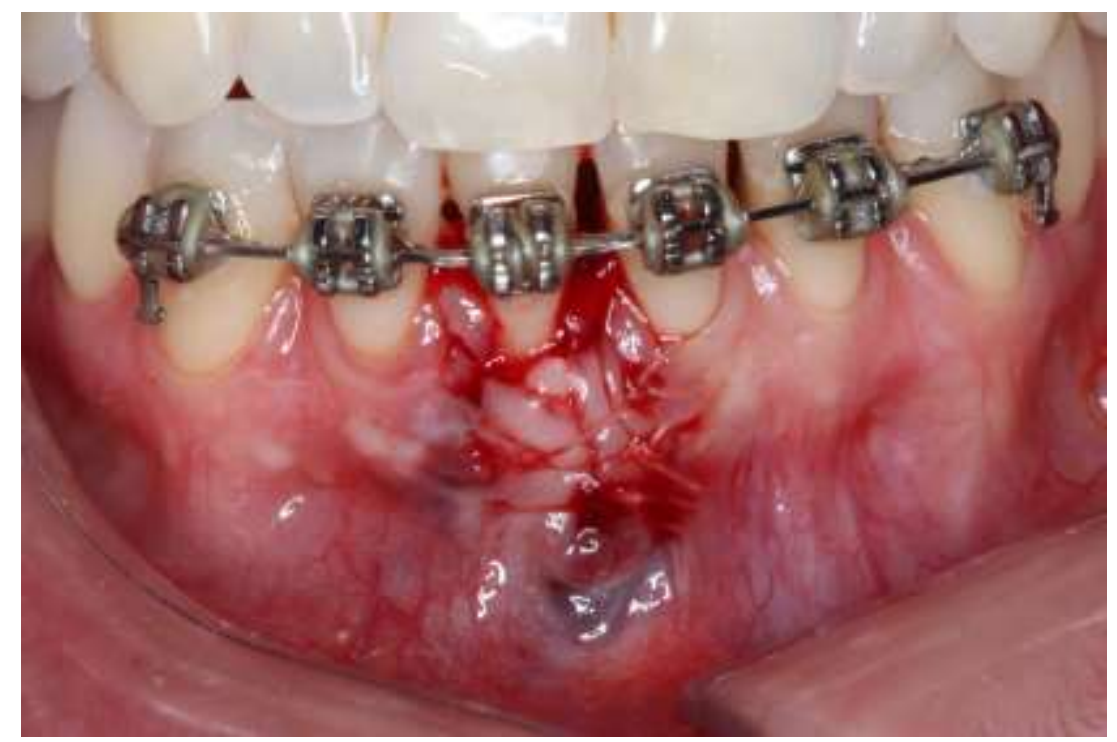

Source: Authors.

After stabilization of the graft and coronal movement of the flap, the flap was sutured with Vicryl 5-0 (Ethicon) wire (Figure 7) and postoperative recommendations were given, which included the use of $0.12 \%$ chlorhexidine, analgesic and antibiotic. 


\section{Treatment outcome}

The treatment proposed allowed a satisfactory result (Figure 8).

Figure 8. Postoperative control after one month.

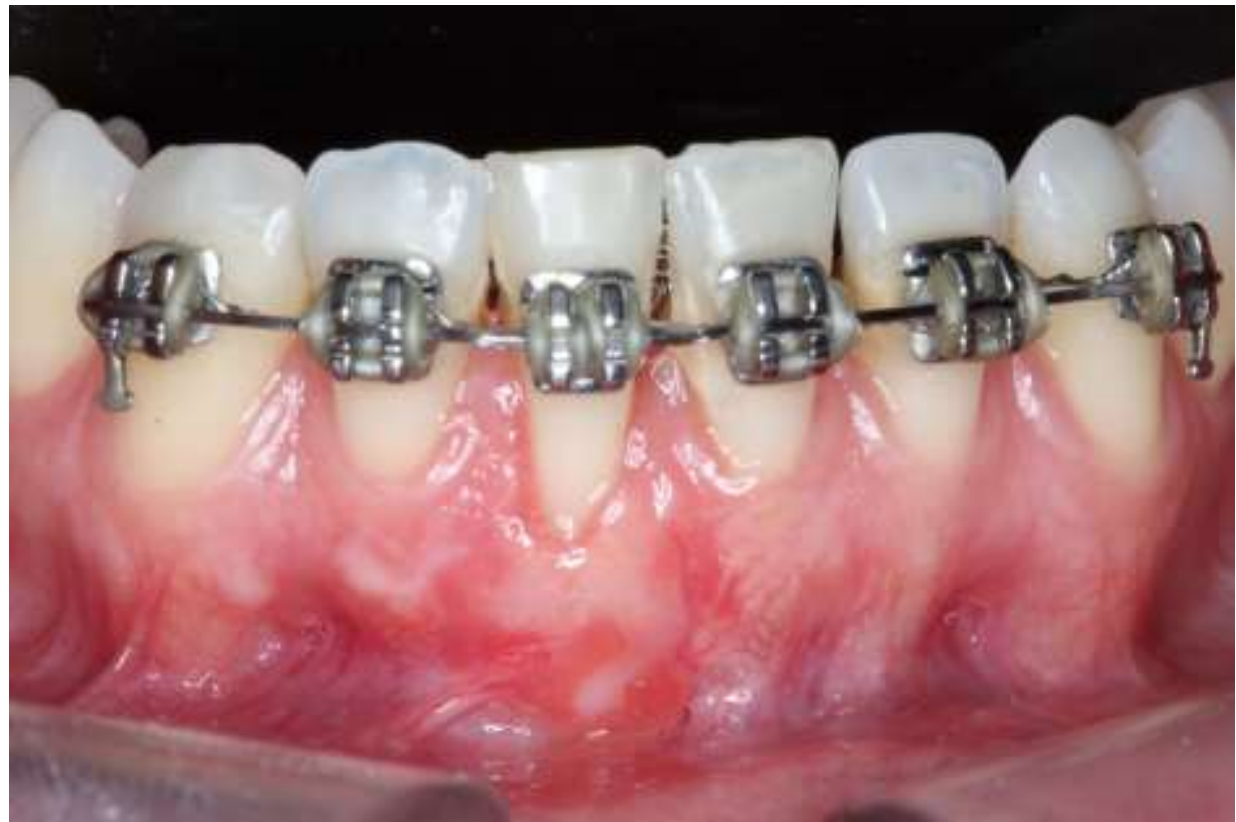

Source: Authors.

It was possible to observe the covering of approximately $85 \%$ of the root, the formation of a thicker biotype with increase of the keratinized mucosa band and the return of the clinical signs of normality of the gingival tissue (Figure 8). These results provide a very favorable prognosis regarding the maintenance of the dental element, since it facilitates the hygiene on the part of the patient and the stability of the gingival margin by the alteration of the periodontal biotype. In addition, the result had a positive impact on the patient's personal satisfaction (Figure 9).

Figure 9. Postoperative control after four months.

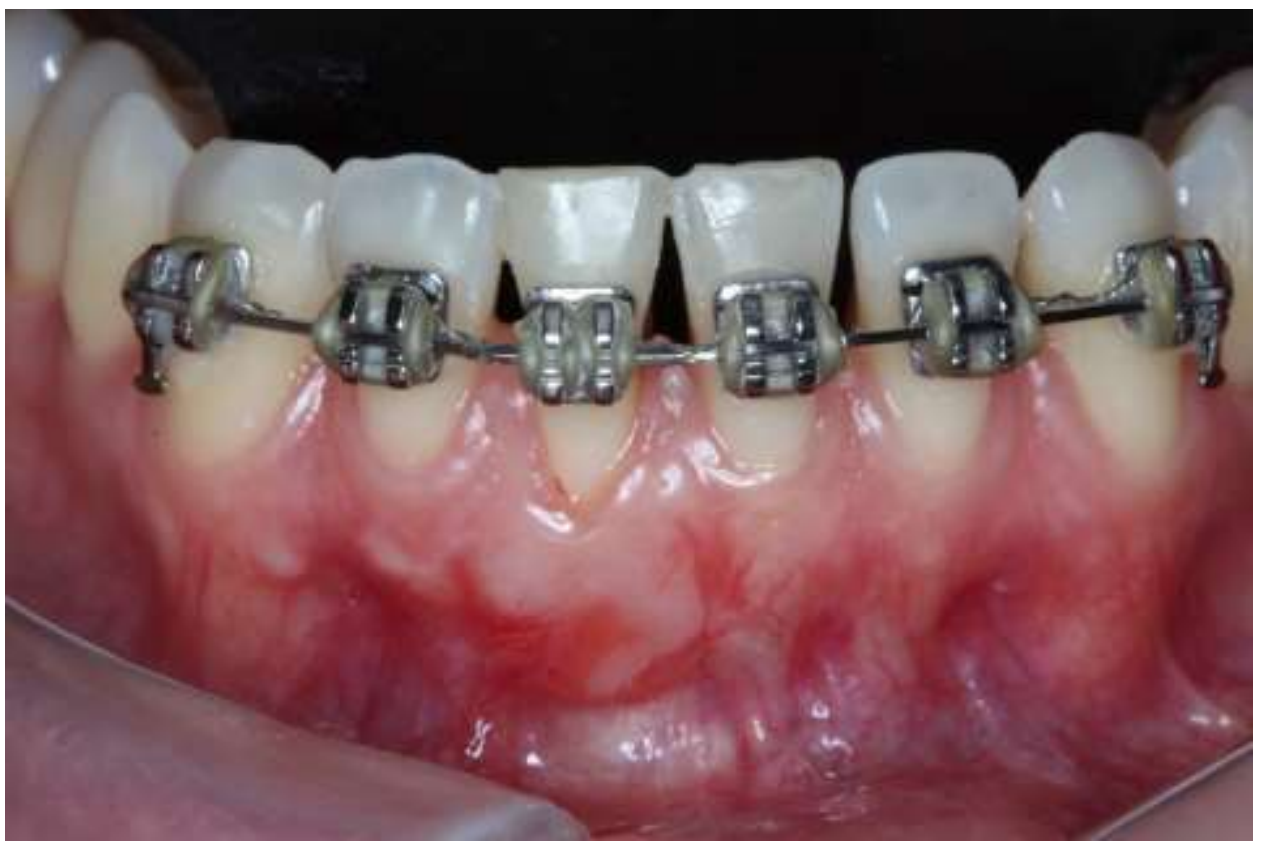

Source: Authors. 
Figure 10. Postoperative control after fourteen months.

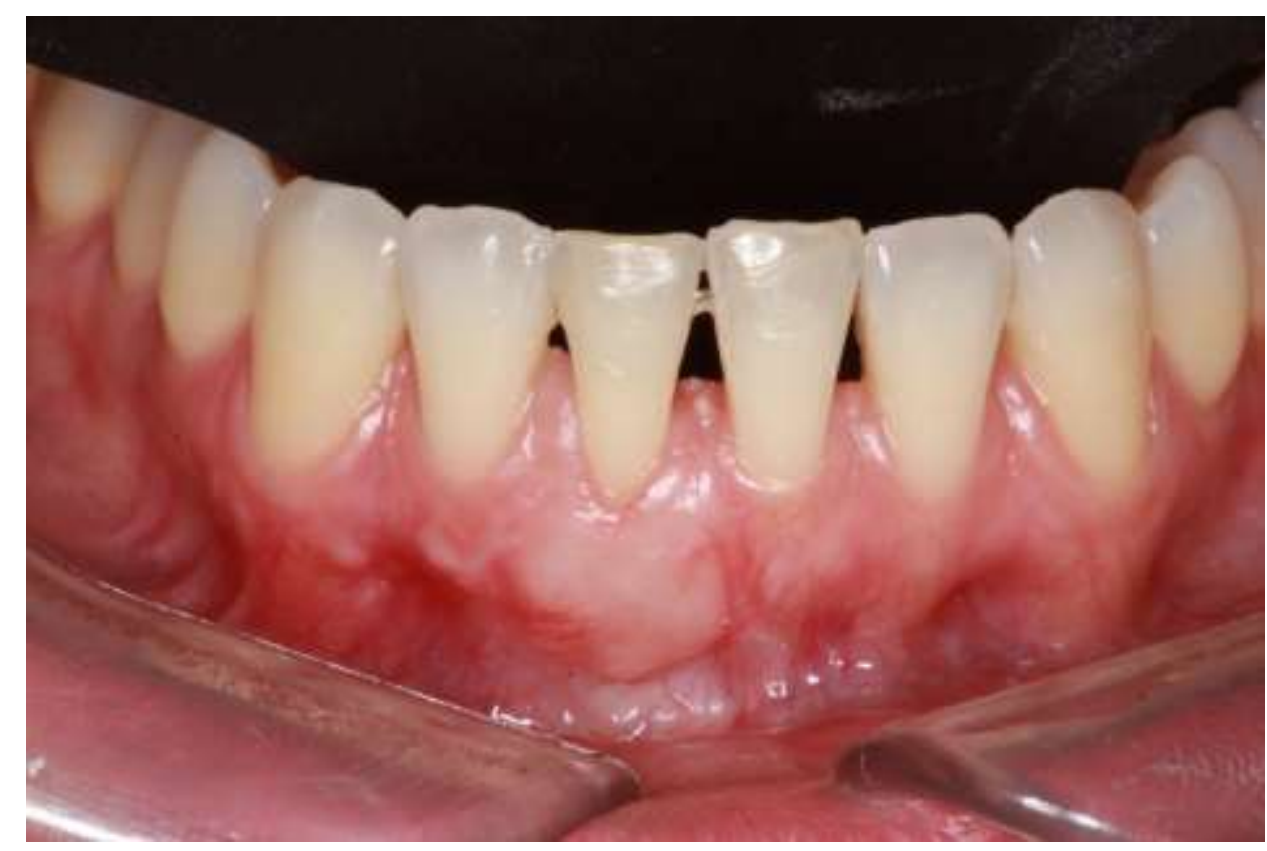

Source: Authors.

In a control of 04 (four) months (Figure 9) and 14 (fourteen) months (Figure 10), the health and stability of the gingival tissues can still be observed.

\section{Discussion}

It can be stated that orthodontic treatment requires clinical planning by a qualified professional, since factors, such as the periodontal type and the gingival conditions of the patient, as well as the collaboration in the control of the biofilm effected by him, support the successful orthodontic treatment (Kahn et al., 2013). Therefore, gingival recessions, caused by the accumulation of the dental biofilm, may be exacerbated by improperly exercised dental movements through excessive force that does not act in accordance with the response of periodontal tissues (Ong \& Wang, 2002; Re et al., 2004; Melsen and Allais D, 2005; Richman, 2011; Henriques \& Guimarães, 2012).

The literature suggests that some aspects, such as the initial position of the dental element (Andlin-Sobocki and Persson, 1994), inclination (Artun \& Krogstad, 1987) and gingival thickness (Yared et al., 2006) may influence the establishment of gingival recession. Orthodontic movement with the objective of realigning dental elements through vestibularization or lingualization is able to guide repositioning of soft tissues during bone remodeling, including in the interproximal sites with the establishment of contact points between the dental elements (Melsen \& Allais D, 2005). However, the more proclined the dental elements present (for the vestibular or lingual / palatal region), the higher the incidence and severity of gingival recession (Joss-Vassalli et al., 2010).

Although the literature reports that root regrowth may not occur (Deng et al., 2010), Allais and Melsen (2003) showed that the movement of incisor vestibularization increased the length of the dental arch and this increase resulted in a positive impact on the level gingival (Allais \& Melsen, 2003; Melsen \& Allais D, 2005). The observed increase in arch length can also be achieved through a distal displacement of the molars (Allais \& Melsen, 2003). The authors found that the areas of gingival recession were significantly reduced (Re et al., 2004). Before this, the orthodontic treatment, a protocol should be performed, which should include scaling and corono-radicular straightening, the removal of biofilm retentive factors and the oral hygiene 
as well as the diet orientation (Harfin, 2004). In some cases, however, in the presence of gingival recession, it is necessary to retrude the dental elements, rather than the movement of vestibularization, to facilitate the repositioning of the gingival tissue (Ngan et al., 1991).

Although some authors report that the amount of proclination of the dental elements does not correlate with the changes in the periodontium (Melsen \& Allais D, 2005), it is understood that the system of forces that generates tooth movement has the objective of distributing as much as possible forces, avoiding local necrosis and ischemia of the periodontal ligament (Allais \& Melsen, 2003). Tugnait e Clerehugh (2001) discuss the importance of dental position in the alveolar bone, because when the movement occurs within the alveolar bone, the risk of occurrence of gingival recession is small. Therefore, it is important to emphasize that a controlled proclination movement, under the maintenance of good oral hygiene through the patient, does not cause risks to the periodontium (Allais \& Melsen, 2003).

With regard to the gingival biotype, gingival recession is more present in dental elements presenting with a thin and narrow gingival biotype than in those that exhibit thick biotype (Kahn et al., 2013). For the orthodontic movement of areas with thin and narrow biotype, it is recommended the intervention of a surgical periodontal treatment in regions that can cause gingival recession, making them thicker and wider, which facilitates hygiene (Re et al., 2004). Statistically significant differences are found in the prevalence of gingival recession between the thin and thick gingival biotypes. However, when comparing the beginning and the end of an orthodontic treatment, there is no significant difference between the groups (Melsen \& Allais, 2005).

The presence of inserted gingiva serves as a barrier between the tooth and the alveolar mucosa, being essential for the maintenance of gingival health, prevention of recession and maintenance of connective tissue fixation. Patients with finalized orthodontic treatment may have lower incisors with an inadequate range of keratinized mucosa, which includes inserted gingiva and free marginal gingiva (Ngan et al, 1991). Therefore, a surgical procedure may be proposed to create a new zone of keratinized gingiva prior to orthodontic treatment in patients who have a minimum width of keratinized tissue (Ngan et al, 1991; Allais and Melsen, 2003), but minimum widths of keratinized gingiva (less than $2 \mathrm{~mm}$ ) appear to be able to withstand the stresses of orthodontic movements (Ngan et al., 1991).

Vestibular recession tends to decrease with retrusion of mandibular incisors even in the presence of moderate inflammation and poor oral hygiene (Ngan et al., 1991), and an improvement of the existing recession is observed if orthodontic treatment is performed under controlled biomechanics and good periodontal conditions, making the risk of damage to the dental elements small (Allais \& Melsen, 2003). There is evidence that there is no statistically significant difference in the size of gingival recession in pre and post-orthodontic times (Allais \& Melsen, 2003; Melsen \& Allais D, 2005), even though there is a biased aspect in the vast majority of orthodontic articles as a predisposing factor of the recession, and not as a possible combination therapy.

In the case reported, gingival recession was initiated by the accumulation of the biofilm, probably due to the difficulty of hygienization of the area favored by the most vestibularized position of the dental element and a deficiency of keratinized mucosa. An accurate diagnosis and well-designed treatment plan were the factors that contributed to the success of the treatment. The multidisciplinary approach, involving the area of Periodontics and Orthodontics was essential for the result.

\section{Conclusion}

In your conclusion section, write a final paragraph in which you will tell readers what suggestions you have for future researches and work.

Through this case report, it is observed that the multidisciplinary procedure between Orthodontics and Periodontics is essential for the treatment of gingival recessions that have poor positioning as a predisposing factor for their triggering. After 
treatment and during the control period, a stability of the gingival tissues was observed, possibly due to the change in the periodontal biotype.

For future researches and work we highlight the importance of ongoing work examining the multidisciplinary approach, involving the area of Periodontics and Orthodontics.

\section{References}

Afonso, P. H., \& Guimarães, G. (2016). Evaluation of the levels of gingival recession present in dentistry students of the Faculty of São Lucas - Porto VelhoRO. Revista Saber Científico, 2(1), 1-11.

Allais, D., \& Melsen, B. (2003). Does labial movement of lower incisors influence the level of the gingival margin? A case-control study of adult orthodontic patients. The European Journal of Orthodontics, 25(4), 343-352.

Andlin-Sobocki, A., \& Persson, M. (1994). The association between spontaneous reversal of gingival recession in mandibular incisors and dentofacial changes in children. A 3-year longitudinal study. The European Journal of Orthodontics, 16(3), 229-239.

Årtun, J., \& Krogstad, O. (1987). Periodontal status of mandibular incisors following excessive proclination A study in adults with surgically treated mandibular prognathism. American Journal of Orthodontics and Dentofacial Orthopedics, 91(3), 225-232.

Bon, C. G., Molina, G. O., \& da Rosa Gaidzinski, P. (2004). Use of acellular dermal matrix for root coverage. RGO-Revista Gaúcha de Odontologia, 53 (2): 85-164.

Cairo, F. (2017). Periodontal plastic surgery of gingival recessions at single and multiple teeth. Periodontology 2000, 75(1), 296-316.

Deng, H., Miao, D., Liu, J., Meng, S., \& Wu, Y. (2010). The regeneration of gingiva: its potential value for the recession of healthy gingiva. Medical hypotheses, 74(1), 76-77.

Ericsson, I., Tehlander, B., Lindhe, J., \& Okamoto, H. (1977). The effect of orthodontic tilting movements on the periodontal tissues of infected and non-infected dentitions in dogs. Journal of clinical periodontology, 4(4), 278-293.

Ericsson, I., Thilander, B., \& Lindhe, J. (1978). Periodontal conditions after orthodontic tooth movements in the dog. The Angle Orthodontist, 48(3), 210-218.

Esposito, M., Grusovin, M. G., Papanikolaou, N., Coulthard, P., \& Worthington, H. V. (2009). Enamel matrix derivative (Emdogain $\left.{ }^{\circledR}\right)$ for periodontal tissue regeneration in intrabony defects. Cochrane database of systematic reviews, (4).

Harfin JF (2004). What is the minimum amount of insertion period required to perform orthodontic movements? Revista Dental Press de Ortodontia $e$ Ortopedia Facial, 9 (1), 145 -157.

Heitz-Mayfield, L. J. A., Trombelli, L., Heitz, F., Needleman, I., \& Moles, D. (2002). A systematic review of the effect of surgical debridement vs. non-surgical debridement for the treatment of chronic periodontitis. Journal of clinical periodontology, 29, 92-102.

Ji, J. J., Li, X. D., Fan, Q., Liu, X. J., Yao, S., Zhou, Z., ... \& Shen, Y. (2019). Prevalence of gingival recession after orthodontic treatment of infraversion and open bite. Journal of Orofacial Orthopedics/Fortschritte der Kieferorthopädie, 80(1), 1-8.

Joss-Vassalli, I., Grebenstein, C., Topouzelis, N., Sculean, A., \& Katsaros, C. (2010). Orthodontic therapy and gingival recession: a systematic review. Orthodontics \& craniofacial research, 13(3), 127-141.

Kahn, S., Menezes, C. C. D., Imperial, R. C., Leite, J. D. S., \& Dias, A. T. (2013). Influence of periodontal biotype in Implantology and Orthodontics. Revista Brasileira de Odontologia, 70(1), 40-45.

Machado, A. W., MacGinnis, M., Damis, L., \& Moon, W. (2014). Spontaneous improvement of gingival recession after correction of tooth positioning. American Journal of Orthodontics and Dentofacial Orthopedics, 145(6), 828-835.

Matsumura, T., Ishida, Y., Kawabe, A., \& Ono, T. (2017). Análise quantitativa da relação entre os incisivos superiores e o canal incisivo por tomografia computadorizada de feixe cônico em uma população japonesa adulta. Progress in Orthodontics, 18 (1), 1-6.

Melsen, B., \& Allais, D. (2005). Factors of importance for the development of dehiscences during labial movement of mandibular incisors: a retrospective study of adult orthodontic patients. American Journal of Orthodontics and Dentofacial Orthopedics, 127(5), 552-561.

Miller Jr, P. D. (1985). A classification of marginal tissue recession. The International journal of periodontics \& restorative dentistry, 5: 8-13.

Morris, J. W., Campbell, P. M., Tadlock, L. P., Boley, J., \& Buschang, P. H. (2017). Prevalence of gingival recession after orthodontic tooth movements. American Journal of Orthodontics and Dentofacial Orthopedics, 151(5), 851-859.

Ngan, P. W., Burch, J. G., \& Wei, S. H. (1991). Grafted and ungrafted labial gingival recession in pediatric orthodontic patients: effects of retraction and inflammation. Quintessence international, 22(2).

Ong, MM e Wang, HL (2002). Tratamento periodôntico e ortodôntico em adultos. American Journal of Orthodontics and Dentofacial Orthopaedics , 122 (4), $420-428$.

Pereira, A. S, Shitsuka. D. M., Parreira F. J., \& Shitsuka, R. (2018). Metodologia da pesquisa científica. UFSM. 
Research, Society and Development, v. 10, n. 6, e36510613526, 2021

(CC BY 4.0) | ISSN 2525-3409 | DOI: http://dx.doi.org/10.33448/rsd-v10i6.13526

Polson, A., Caton, J., Polson, A. P., Nyman, S., Novak, J., \& Reed, B. (1984). Periodontal response after tooth movement into intrabony defects. Journal of Periodontology, 55(4), 197-202.

Re, S., Cardaropoli, D., Abundo, R., \& Corrente, G. (2004). Reduction of gingival recession following orthodontic intrusion in periodontally compromised patients. Orthodontics \& craniofacial research, 7(1), 35-39.

Richman, C. (2011). Is gingival recession a consequence of an orthodontic tooth size and/or tooth position discrepancy?" A paradigm shift”. Compendium of Continuing Education in Dentistry, 32(4), e73-9.

Rotundo, R., Bassarelli, T., Pace, E., Iachetti, G., Mervelt, J., \& Prato, G. P. (2011). Orthodontic treatment of periodontal defects. Part II: A systematic review on human and animal studies. Progress in orthodontics, 12(1), 45-52.

Sharma Sharma, K., Mangat, S., Kichorchandra, M. S., Handa, A., Bindhumadhav, S., \& Meena, M. (2017). Correlation of orthodontic treatment by fixed or myofunctional appliances and periodontitis: a retrospective study. The journal of contemporary dental practice, 18(4), 322-325.

Tugnait, A., \& Clerehugh, V. (2001). Gingival recession —its significance and management. Journal of dentistry, 29(6), 381-394. 1

Yared, K. F. G., Zenobio, E. G., \& Pacheco, W. (2006). Periodontal status of mandibular central incisors after orthodontic proclination in adults. American Journal of Orthodontics and Dentofacial Orthopedics, 130(1), 6-e1.

Zanicotti, D., Deliberador, T., Zielak, J., Fernando, A., \& Giovanini, C. (2009). Coronally advanced flap and subepithelial connective tissue graft in the treatment of multiple recession-type defects. Perspectives in Oral Sciences, 1, 36-8.

Zavanelli, A. C., Mazaro, J. V. Q., Nóbrega, P. I., FalcÓn-antenucc, R. M., \& Zavanelli, R. A. (2018). Data collection about failures in fixed partial dentures: 1-year monitoring. RGO-Revista Gaúcha de Odontologia, 66(3), 250-256. 